\title{
Molecular Diagnosis in Differentiating Active and Inactive Forms of Hepatitis B Virus Carriers
}

\author{
Salah Tofik Jalal Balaky $^{\mathrm{a}}$ Saeed Ghulam Hussain $^{\mathrm{b}}$ Amer Ali Khaleel $^{\mathrm{c}}$ Furat Tahseen Sabeer $^{\mathrm{d}}$ \\ Ahang Hasan Mawlood ${ }^{\mathrm{e}}$ \\ ${ }^{A, c, e}$ Department of Medical Microbiology, College of Health Sciences-Hawler Medical University, Erbil, \\ Iraq. \\ ${ }^{b}$ College of Medicine-Hawler Medical University, Erbil/ Iraq. \\ ${ }^{d}$ Public Health Laboratory, Erbil, Kurdistan Region, Iraq.
}

sbalaky2013@gmail.com saeed.ghulam@med.hmu.iq.firat_erbil@yahoo.com

Submission date:- 2/10/2018 Acceptance date:- 16/10/2018 Publication date:- 14/11/2018

Keywords: Hepatitis, Quantitative, $H B V-D N A$, active $H B V$, inactive $H B V$.

\begin{abstract}
Background \& objectives: Introducing a nucleic acid test program is aimed to diagnose and reduces the risk of viral infection or transmission. DNA assay for HBV can detect infection in the windows period, chronic occult infection and can discriminate between active and inactive HBV infection. This cross-sectional study designed to diagnose, analyze HBV infection and to differentiate active from inactive infection based on viral DNA detection. Methods: Blood samples were collected from 256 patients previously diagnosed on the clinical ground as hepatitis B seropositive in Erbil Central Lab. The viral nucleic acid quantitative assessment was done for the collected samples using RT-PCR. Qsquare was performed for statistical analysis. Results: Out of 256 collected blood samples 93 (36.3\%) showed HBVDNA positive titers above $50 \mathrm{IU} / \mathrm{ml}$. Among positive subjects, $67(72.04 \%)$ was categorized as inactive carriers $(<$ 2000-20.000 IU/ml HBV-DNA titers). Conclusions: The data produced from this study confirmed the importance of the RT-PCR technique in sensitivity and reliability as a superior diagnostics tool specifically in differentiating active from inactive HBV carriers.
\end{abstract}

\section{1- Introduction}

Hepatitis B virus (HBV) is a worldwide risk health problem, about two billion people have HBV serologic markers [1]. On the clinical ground, more than 360 million people are chronically infected [2]. In many countries, molecular techniques have been introduced as routine screening methods [3]. Screening for HBV via DNA amplification is efficient in minimizing HBV transmission via blood and blood products [4]. Periodic monitoring of blood HBV-DNA is of paramount importance in the management of chronic hepatitis B infection [5]. Molecular techniques can be used for differentiation between active and inactive HBV infection. Active HBV carriers with high viral load is a remarkable risk factor for both incidence and mortality of HCC [6 ],[7], whereas inactive HBV carrier denotes the low rate of HBV reactivation, HCC, progressions to cirrhosis and good prognosis [8]. The viral genome is a $3.2 \mathrm{~kb}$ circular partially duplex DNA molecule with the circularity conserved by 5 ' ends. The genome is made only from condensed coding regions with four open reading frames (ORFs) [9]. For quantification of HBV DNA laboratory measures how many units of the viral DNA are found in a $\mathrm{ml}$ of blood (international units per milliliter or $\mathrm{IU} / \mathrm{ml}$ ). The viral DNA levels range from thousands up to millions, referred as a high rate of HBV replication. However, levels-less than 2,000 IU/ml referred to as an "inactive" infection or undetectable [10], [11]. During HBV infection, markers can be detected in sera samples using immunoassays. For example, patient sera that contain anti-HBs indicates immunity from past infections or vaccinations, and a patient with anti-HBe antibodies in their sera is considered as a spontaneous resolution of infection or therapy-induced improvement [12 and 13]. One of the serological methods using for diagnosis of HBV is enzyme immune assays (EIAs). ELISA test is a qualitative serological test for the diagnosis of HBsAg human serum. 
However, DNA amplification using RT-PCR is potentially a more sensitive assay [14]. RT-PCR for example used as a molecular technique for detection and quantification of the viral genome, which can also discriminate between active and inactive infection [15]. The aim of this study was to discriminate between active and inactive HBV infections based on DNA titers.

\section{2- Materials and Methods}

For this cross-sectional study, blood samples were collected from 256 patients suspected on the clinical pictures as viral hepatitis, referred to Erbil Central Laboratory, from June to September 2017 for HBV DNA screening. Some patients were referred because of a history of Jaundice confirmed serologically using HBs Ag testing. Other patients were referred as follow up for assessment of viral load and treatment response. Both sexes were included (154 males and 102 females); with age range between 20-60 years. This project was approved at the first site by the Scientific and Research Ethics Committee at the College of Health Sciences, Hawler Medical University/ Iraq.

Five ml of venous blood were collected using EDTA tubes and centrifuged at 1000rpm for 5 minutes and patients' plasma was separated. Viral HBV DNA was extracted from a $200 \mathrm{uL}$ aliquot of serum using a Qiagen mini blood kit (Qiagen, Hilden, Germany) according to manufacturer instructions. Viral loads of HBV DNA were estimated by RTPCR (HBV RG PCR Artus Germany).For RT-PCR reaction a 50 $\mu 1$ reaction mixture was used, which contains: $30 \mu 1$ of Master-mix (Buffer, dNTP, primer, probe, and enzymes) and HBV RG inhibition control mixed with $20 \mu 1$ of DNA template. HBV-Taq I forward primer: CAA CCT CCA ATC ACT CAC CAAC and HBV- Taq 2 reverse primer: ATA TGA TAA AAC GCC GCA GAC AC were used [16]. RT-PCR in which Rotorgene 3000 was then used to detect HBV-DNA according to the manufactures instructions. The RT-PCR cycling parameters consisted of denaturation at $95^{\circ} \mathrm{C}$ for 15 seconds, $55^{\circ} \mathrm{C}$ for 30 seconds and $72^{\circ} \mathrm{C}$ for 15 seconds. The results were considered positive if a signal was detected in cycling A FAM, whereas no signal detection indicated as negative results. The quantitation of HBV DNA was performed for all blood samples and the results were considered positive and significant if viral load was more than $1 \times 10^{5}$ viral copies/ ml. Titers less than 50IU were considered as negative for HBV DNA. The screened results were categorized according to positive HBV DNA titers into inactive, gray zone and active carriers.

\section{3- Statistical Analysis}

For statistical analysis, SPSS 23.0 was used. HBV titers expressed as means \pm SE. Comparisons between active and inactive carriers T-tests were depended. Comparisons between multiple groups were performed by ANOVA. P values $\leq$ 0.05 was considered as statistically significant.

\section{4- Results}

The results of the present study delineated the frequency of HBV-DNA among screened patients. Accordingly, HBV-DNA was positive in $36 \%$ of the tested patients; the frequency of HBV-DNA positive results constituted $42 \%$ and $27 \%$ for males and females respectively (Table 1). The distribution of HBV-DNA titers revealed the highest positively rate at titer $101-500 \mathrm{IU} / \mathrm{ml}$ and $>20.000 \mathrm{IU} / \mathrm{ml}$ (20\% and 23\% respectively) (Table 2). On the other hand, Table (3) showing the distribution of means of HBV-DNA titers, and statistically the differences were highly significant $(\mathrm{p} \leq 0.001)$. The discrimination of active and inactive HBV infection among HBV-DNA blood samples was based on three HBV-DNA titers (8). Thus, inactive carriers ( $\geq 50-2000 \mathrm{IU} / \mathrm{ml})$; Gray zone carriers (2001-20.000 IU/ml) and active carriers (> $20.000 \mathrm{IU} / \mathrm{ml}$ ) were categorized among the total HBV-DNA positive blood screened (Table 4). Thus, the frequency of HBV infection as inactive, gray zone (as extended inactive) to active group revealed $46 \%, 21 \%$, and $30 \%$ respectively. Table 5 delineated highly significant differences between the mean titers of HBV-DNA inactive and active carrier $(\mathrm{p} \leq 0.05)$.

Table 1: Frequencies of HBV DNA positivity according to the gender.

\begin{tabular}{ccccc}
\hline Gender & Positive PCR & Negative PCR & Total & P Value \\
\hline Male & $65(42.20 \%)$ & $89(57.79 \%)$ & 154 & $\leq 0.001$ \\
Female & $28(27.45 \%)$ & $74(72.54 \%)$ & 102 & \\
Total & $93(36.3232 \%)$ & $163(63.67 \%)$ & 256 & \\
\hline
\end{tabular}


Table 2: Percentages of $\mathrm{HBV}$ DNA according to titer range among patients

HBV DNA PCR titers IU/ml

\begin{tabular}{ccccccc}
\hline$<50 \mathrm{IU}$ & $50-100$ & $101-500$ & $501-1000$ & $1001-2000$ & $2001-20.000$ & $>20.000$ \\
\hline 21 & 4 & 23 & 9 & 9 & 21 & 27 \\
$(18.42 \%)$ & $(3.50 \%)$ & $(20.17 \%)$ & $(7.89 \%)$ & $(7.89 \%)$ & $(18.42 \%)$ & $(23.68 \%)$ \\
\hline
\end{tabular}

Table 3: Mean HBV DNA titers among positive patients screened.

\begin{tabular}{|c|c|c|c|c|c|c|}
\hline \multicolumn{6}{|c|}{ PCR titers IU/ml } & \multirow[t]{2}{*}{ pValue } \\
\hline$\geq 50-100 n=4$ & $101-500$ & $501-1000$ & $1001-2000$ & $2001-20.000$ & $>20.000$ & \\
\hline & $n=23$ & $\mathrm{n}=9$ & $\mathrm{n}=9$ & $\mathrm{n}=21$ & $\mathrm{n}=27$ & \multirow[b]{2}{*}{0.001} \\
\hline $71.25 \pm 5.66$ & $284.60 \pm 21.38$ & $755.0 \pm 39.95$ & $1425.3 \pm 70.95$ & $\begin{array}{c}3767.14 \pm \\
405.32\end{array}$ & $\begin{array}{l}120936819 \pm \\
36526296.47\end{array}$ & \\
\hline
\end{tabular}

Table 4: Percentage of active and inactive $\mathrm{HBV}$ infection among patients according to titers.

\begin{tabular}{ccc}
\hline Inactive carriers & Gray zone carriers & Active carriers \\
\hline$\geq 50-2000 \mathrm{IU} / \mathrm{ml}$ & $2001-20.000 \mathrm{IU} / \mathrm{ml}$ & $>20.000-990885600 \mathrm{IU} / \mathrm{ml}$ \\
$45(48.38 \%)$ & $21(22.58 \%)$ & $27(29.03 \%)$ \\
\hline
\end{tabular}

Table 5: Mean HBV DNA titers in active and inactive patients.

\begin{tabular}{ccc}
\hline & PCR HBV DNA titers & PValue \\
\hline Inactive carriers & Active carriers & $\leq 0.01$ \\
$\mathrm{n}=66$ & $\mathrm{n}=27$ & \\
$1599.53 \pm 225.70$ & $120936819.9 \pm 36526296.47$ & \\
\hline
\end{tabular}

\section{5- Discussion}

The detection of HBV infection is vital for diagnosis, follow up the study and for controlling spread in community with the limited spectrum of disease range for acute to chronic, often progress to liver cirrhosis and HCC depends on the interplay between viral and host factors [17-19]. Two phases characterize the acute exposure to HBV namely immune-tolerant and immune reactive phase [8]. But some patients remain in an active carrier with serum level of HBV-DNA < $2000 \mathrm{IU} / \mathrm{ml}$; while others progress to HBe antigen-negative chronic hepatitis B [20]; as HBe regarded as markers for HBV replication and increased risk of patient infectivity. The present study revealed HBV DNA positivity in $36.32 \%$ patients (previously diagnosed serologically) diagnosed on clinical pictures as HBV infection (Table 1). These results were disagreed with others who reported $60.5 \%, 71.4 \%$ and $82.2 \%$ as positive for HBV infection [21-23]. Of these patients, 66 (70.97\%) were categorized as inactive carriers. While the remaining were active carriers $(29.03 \%$ ), with DNA viral titers $>20,000 \mathrm{IU} / \mathrm{ml}$ (Table 5). The impact of genders revealed $42 \%$ males and $27 \%$ females HBV DNA positivity rate $(\mathrm{P}$ value $\leq 0.01$ ) (Table 1), this was disagree with what reported by [23] and agree with [21]. Screening for HBV viral DNA amplification is efficient in minimizing HBV transmission via blood and blood products besides as a diagnostic tool [4]. Four phases characterize chronic hepatitis B (CHB) infection namely immune tolerant, immune clearance, immune control and immune escape [19]. These four phases in CHB infection neither take place sequentially [24] nor occur in all infected people. Of all 4 phases, only patients that require antiviral and immune modulators therapy those in either the immune clearance or immune escape phase [19]. Accordingly, the 
selective quantitation using (RT-PCR assay is critical for assessment of serum HBV DNA levels after antiviral therapy; for HBV diagnosis; discrimination between active and inactive HBV infection and for the diagnosis of acute HBV infections [19 and 25]. This holds true for the patients in the present study because some were clinically suspected as viral hepatitis, and others were follow up that needs to discriminate of active from inactive and as treatment response. Especially the HBV DNA levels can shift from low or undetectable to >2,000,000 IU/mL [26] and some inactive carriers could occasionally have HBV DNA levels between 2000-20,000 IU/ml. Thus, single HBV DNA level between 2,000-20,000 IU/ml categorized to be a "gray area" which can refer to both active CHB and inactive carriers [26]. In the present study, 21.64\% patients were in the gray zone carriers (Table 4). Accordingly, clinicians should be aware of the importance and significance of serial HBV DNA measurements and lifelong follow-up to confirm maintenance of inactive carrier state [8]. A newly diagnostic criterion has been revised for inactive carrier based on detection of lower ALT upper limits of normal levels of $30 \mathrm{IU} / \mathrm{ml}$ for men and $19 \mathrm{IU} / \mathrm{ml}$ for women [26]. But, still, the EASL acknowledges that inactive carriers might exist with DNA levels between 2,000-20,000 IU/ ml [20].

\section{CONFLICT OF INTERESTS}

There are no conflicts of interest.

\section{References}

[1] Lin, Hong, Hong Zhao, Xinyi Tang, Wenjia Hu, Nizheng Jiang, Shaowen Zhu, and Chengyin Huang. "Serological patterns and molecular characterization of occult hepatitis b virus infection among blood donors." Hepatitis monthly 16, no. 10, 2016.

[2] Block, Timothy M., Haitao Guo, and Ju-Tao Guo. "Molecular virology of hepatitis B virus for clinicians." Clinics in liver disease 11.4: pp. 685-706, 2007.

[3] Allain, Jean-Pierre, and Laura Cox. "Challenges in hepatitis B detection among blood donors." Current opinion in hematology 18, no. 6. pp. 461-466, 2011.

[4] Kishk, Rania, Nader Nemr, Abeer Elkady, Mohamed Mandour, Mohamed Aboelmagd, Nevene Ramsis, Mohamed Hassan et al. "Hepatitis B surface gene variants isolated from blood donors with overt and occult HBV infection in north eastern Egypt." Virology journal 12, no. 1. pp. 153, 2015.

[5] Su, Tung-Hung, Ching-Sheng Hsu, Chi-Ling Chen, Chen-Hua Liu, Yi-Wen Huang, Tai-Chung Tseng, Chun-Jen Liu et al. "Serum hepatitis B surface antigen concentration correlates with HBV DNA level in patients with chronic hepatitis B." Antiviral therapy 15, no. 8 pp. 1133, 2010.

[6] Sung, Feng-Yu, Chun-Ming Jung, Chih-Feng Wu, Chih-Lin Lin, Chun-Jen Liu, Yun-Fan Liaw, Keh-Sung Tsai, and Ming-Whei Yu. "Hepatitis B virus core variants modify natural course of viral infection and hepatocellular carcinoma progression." Gastroenterology 137, no. 5, pp. 1687-1697, 2009.

[7] Chan, Henry Lik-Yuen, Chi-Hang Tse, Frankie Mo, Jane Koh, Vincent Wai-Sun Wong, Grace Lai-Hung Wong, Stephen Lam Chan, Winnie Yeo, Joseph Jao-Yiu Sung, and Tony Shu-Kam Mok. "High viral load and hepatitis B virus subgenotype ce are associated with increased risk of hepatocellular carcinoma." Journal of Clinical Oncology 26, no. 2, pp. 177-182.

[8] Pita, Inês, Ana Maria Horta-Vale, Hélder Cardoso, and Guilherme Macedo. "Hepatitis B inactive carriers: An overlooked population?." GE Portuguese Journal of Gastroenterology 21, no. 6, pp. 241-249, 2014.

[9] Guirgis, Bassem SS, Radwa O. Abbas, and Hassan ME Azzazy. "Hepatitis B virus genotyping: current methods and clinical implications." International Journal of Infectious Diseases 14, no. 11: e941-e953, 2010.

[10] Mohammed, G., A. Bassim, and A. Duraid. "Real-Time PCR as a diagnostic tool for HBV infection in Iraq." The Iraqi postgraduate Med. J 11. 2, 2012.

[11] Pita, Inês, Ana Maria Horta-Vale, Hélder Cardoso, and Guilherme Macedo. "Hepatitis B inactive carriers: An overlooked population?." GE Portuguese Journal of Gastroenterology 21, no. 6, pp. 241-249, 2014.

[12] Gerlich, Wolfram H. "Medical virology of hepatitis B: how it began and where we are now." Virology journal 10, no. 1 pp. 239, 2013.

[13] Villar, Livia Melo, Helena Medina Cruz, Jakeline Ribeiro Barbosa, Cristianne Sousa Bezerra, Moyra Machado Portilho, and Letícia de Paula Scalioni. "Update on hepatitis B and C virus diagnosis." World journal of virology 4, no. 4, pp. 323-342, 2015. 
[14] Radii, Intisar Jebbar, and Asmaa Mohammed Saud. "Comparative Assessment between Serological and Molecular Diagnosis for Patients Groups with Hepatitis B Virus." Int. J. Curr. Microbiol. App. Sci 6, no. 3, pp. 742-748, 2017.

[15] Sharma, Narotam, Sahzad Ali, Satish C. Nautiyal, Vikram Singh, Sarita Kumari, Krishan Kumar, Deeksha Agrawal, and Raj K. Singh. "Hepatitis B virus DNA quantification using TaqMan probe and its significance." 2013.

[16] Weinberger, Klaus M., Elisabeth Wiedenmann, Stephan Böhm, and Wolfgang Jilg. "Sensitive and accurate quantitation of hepatitis B virus DNA using a kinetic fluorescence detection system (TaqMan PCR)." Journal of virological methods 85 , no. 1-2, pp. 75-82, 2000.

[17] Gerlich, Wolfram H. "Prophylactic vaccination against hepatitis B: achievements, challenges and perspectives." Medical microbiology and immunology 204, no. 1, pp. 39-55, 2015.

[18] Wang, J., F. M. Lu, and H. Zhuang. "The analysis on the epidemic trend of viral hepatitis in China during recent 10 years (2002-2011)." Chinese journal of hepatology 21, no. 8, pp. 561, 2013.

[19] Dandri, Maura, and Stephen Locarnini. "New insight in the pathobiology of hepatitis B virus infection." Gut 61, no. Suppl 1, pp. i6-i17, 2012.

[20] European Association For The Study Of The Liver. "EASL clinical practice guidelines: management of chronic hepatitis B virus infection." Journal of hepatology 57, no. 1, pp. 167-185, 2012.

[21] Al-Suraifi, Ali Shakir Kamil, Ahmed Darwish Jabbar Al-Rubaie, Sareaa Maseer Gatya Al-Mayahie, Naeem Mohammed Mohsen Al-Abedy. Unusual HBV Mixed Genotype Infections among Hepatitis Type B Iraqi Patients in Wasit Province. Iraq International Journal of Biomedical Engineering and Clinical Science. Vol. 2, No. 1, pp. 1-7, 2016.

[22] Khaled, I. A. A., Ola M. Mahmoud, Abeya F. Saleh, and Emad A. Baioumi. "Prevalence of HBV genotypes in Egypt among hepatitis patients." Journal of American Science 6, no. 11, pp. 185-190, 2010.

[23] Kurdi, Mohiadeen, et al. "Molecular detection of hepatitis B virus (HBV) among voluntary ELISA positive blood donors in Almadinah Almunawwarah." Journal of Taibah University Medical Sciences 9, pp. 166-170, 2014.

[24] Hadziyannis, Stephanos J., and George V. Papatheodoridis. "Hepatitis B e antigen-negative chronic hepatitis B: natural history and treatment." In Seminars in liver disease, vol. 26, no. 02, pp. 130-141, 2006.

[25] Albertoni, Guilherme, Manoel Joao Batista Castelo Girao, and Nestor Schor. "Mini review: current molecular methods for the detection and quantification of hepatitis B virus, hepatitis $\mathrm{C}$ virus, and human immunodeficiency virus type 1." International Journal of Infectious Diseases 25, pp. 145-149, 2014.

[26] Lok, Anna SF, and Brian J. McMahon. "Chronic hepatitis B: update 2009." Hepatology 50, no. 3, pp. 661-662, 2009).

$$
\begin{aligned}
& \text { الخلاصة } \\
& \text { الهذف: استخدام برنامج اختبار الحامض النووي لغرض تشخيص العدوى الفيروسية وتقليل انتقالها. ان فحص الحامض النووي الرايوزى منقوص } \\
& \text { الاوكسجين لفايروس التهاب الكبد نمط B يمكن استخدامه في تشخيص العدوى من خلال فتزة النافذة والمزمنة الغامض ايضا، اضافة الى ذلك استخدام }
\end{aligned}
$$

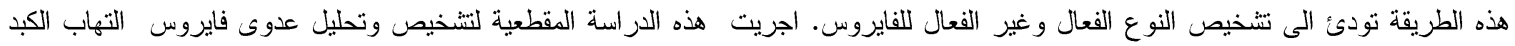

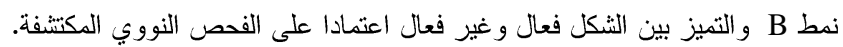

$$
\begin{aligned}
& \text { الطر ائق: تم جمع } 256 \text { عينة الدم من اشخاص تعرضوا سابقا للاصابة بفايروس التهاب الكبد نمط B وارجعوا مختبر الصحة العامة المركزي في }
\end{aligned}
$$

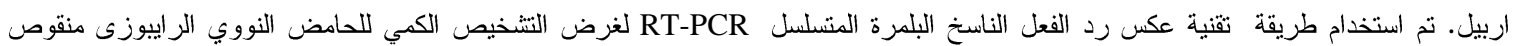

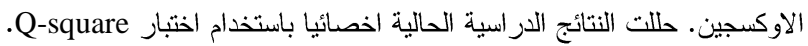

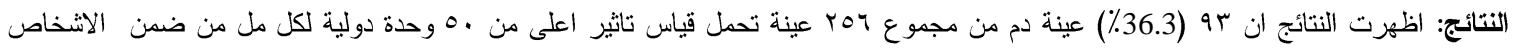

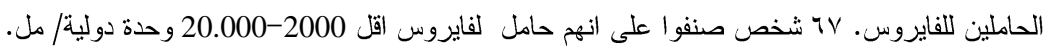

$$
\begin{aligned}
& \text { الاستتتاجات: اظهرت الدراسة الحالية اهمية استخدام تقنية عكس رد الفعل الناسخ البلمرة المتسلسل RT-PCR في حساسيتها وقوتها كاداة معتمدة }
\end{aligned}
$$

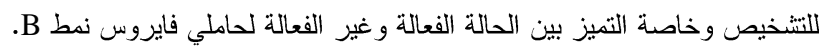

$$
\begin{aligned}
& \text { الكلمات الدالة: التهاب الكبد، الكمية، HBV-DNA، HBV HBV غير نشط. }
\end{aligned}
$$

